\title{
Concept and Building Blocks of a Business Model: A Systematic Literature Review
}

\author{
Bin Gao, Shaofeng Liu, Genhua Pan, and Aira Patrice R. Ong
}

\begin{abstract}
Business model has been drawing attention from both industry and academia. It plays a crucial role in business operations and strategy. In the revolutionary and competitive environment, business model innovation is likely to lead to better business performance. However, there have been diverse interpretations on the concept and building blocks of a business model. The purpose of this paper is to provide some common understanding on the concept and its core building blocks in order to progress to the development of an innovative business model. A systematic literature review has been undertaken to gain insights into the key themes of the topic, before some recommendations for business model development are made.
\end{abstract}

Index Terms-Business model, value beneficiary, value capture, value chain, value creation.

\section{INTRODUCTION}

The term of "business model" has drawn growing interest to both industry and academics in recent years. Many studies have shown the importance of a business model for companies, and that business model innovation has close relationship with an organization's success [1]-[3]. However, the concept of business model is still divided among researchers [4], [5]. In addition, no generally accepted opinions about key components or building blocks of a business model exist. Different researchers tend to give varied descriptions about a business model [6].

There are some studies and systematic literature reviews on business models. For example, Osterwalder and Pigneur have classified business models into five categories [7]. They are (1) separation of business model, (2) "long tail model", (3) multilateral platforms, (4) free as a business model, and (5) open business model. Barth et al. propose a conceptual framework for sustainable business model in argi-food industry based on a systematic literature review covers the papers published from 1990 to 2014 [4]. Both of them provide insights for the business model development, but some of the cases in the literature are out of date. Furthermore, Foss and Saebi have conducted a systematic literature review on business model innovation based on the paper published from 2000 to 2015 and suggest that a conceptual clarification is still needed for this emerging field [5].

As business and global economy are developing at rapid speed in recent years, it is necessary to review the concept and recent development of business models. This paper aims to increase the understanding of business models by including the most recent paper up to 2019. This paper

Manuscript received May 15, 2019; revised August 7, 2019.

Bin Gao, Shaofeng Liu, Genhua Pan, and Aira Patrice R. Ong are with the University of Plymouth, UK (e-mail: tony.gao@plymouth.ac.uk). examines existing definitions of a business model and its key building blocks in order to make recommendations for business model development. The two research questions to be addressed are:

RQ1: What is the essence in the concept of a business model and how has the research on business models evolved?

RQ2: What are the key building blocks of a business model?

\section{Systematic Literature Review Process}

This section covers the research method and research process. In this paper, the Scopus database and ScienceDirect are selected for the systematic literature review because they are comprehensive sources with a strong focus on business studies, science, and medical literature. The research process is shown in Fig. 1 that consists of four stages: planning, searching, refining, and analysis.

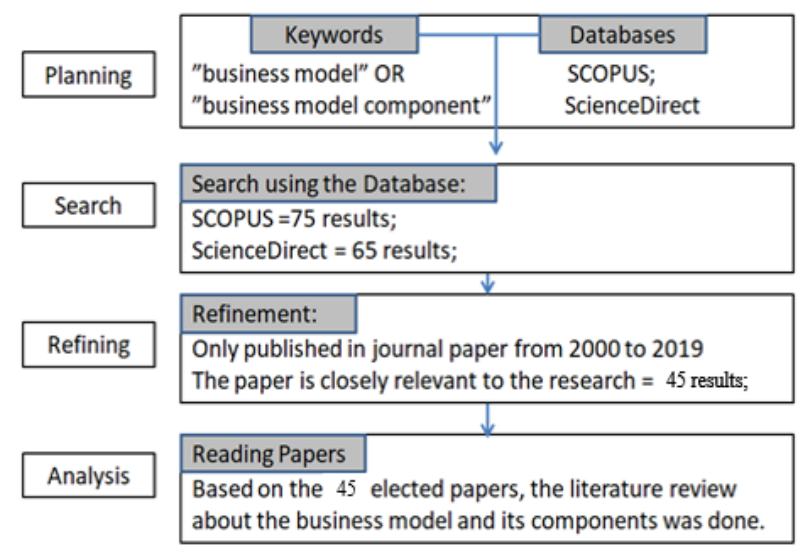

Fig. 1. Research process.

Following the systematic literature review process, we started searching the two databases by using keywords "business model", "business model components" and "business model innovation". Phrases implying similar meanings such as "business model building block" are considered. Boolean operations such as "AND" and "OR" are incorporated in the search. Initially the search returned over 2,000 results. Then we applied a list of inclusion/ exclusion criteria to refine the results, for example, to include only the sources that full-text articles are available, peer-reviewed, with high topic relevance. Repetitive results returned from the two databases are removed. Cross references are considered. Plus two papers recommended by experts in the field. In the end, 45 articles ae selected for the thematic analysis. The distribution of these 45 papers is 
illustrated in Fig. 2. As it can be seen from the Figure, there is a steady growth of interest in the last few years.

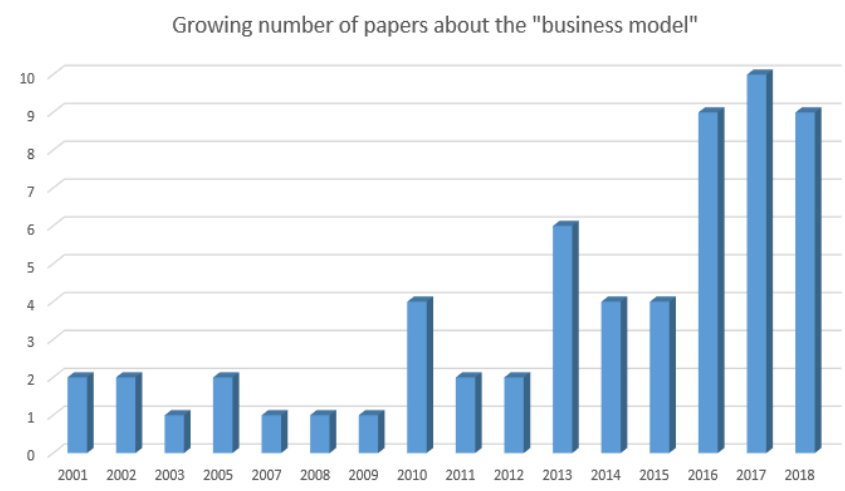

Fig. 2. Paper distribution by year.

Furthermore, the papers are from a variety of academic fields, as illustrated in Fig. 3, ranging from business, social sciences, economics, and environmental sciences etc. It provides the evidence that the business model research is an interdisciplinary research and attracts attention from heterogeneous disciplines.

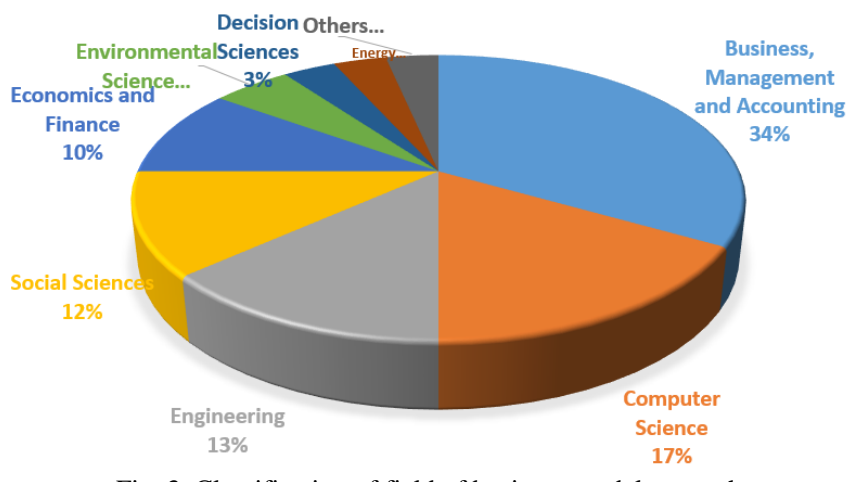

Fig. 3. Classification of field of business model research.

\section{ThEMATIC ANALYSIS}

Thematic analysis focuses on eliciting the main themes by analyzing the collection of literature. Three main themes emerged from the analysis of the 60 papers. First theme is centered around the business model definition. Second theme is about the components of a business model, or the building blocks of a business model. Third theme is sustainable business model. Sustainable business model is an emerging field as some researchers realize that business model concept should not be confined to merely economic aspects [8]-[10]. Some of the sustainable models have been developed from the manufacturing industry [11]-[13]. The framework of a sustainable business model includes four dimensions: life cycle thinking, multiple stakeholders, value exploitation, and the triple bottom lines (i.e. economic, social, and environmental value). There have been a small number of models associated with the healthcare industry [14]. Several studies examined the relationship between business sustainability and health care stakeholders [15]-[17]. There are three key stakeholders in the healthcare industry, including patients, practitioners and policymakers. Lopes et $a l$. argue that the sustainability of a business model plays an important role in hospital management [18].

\section{A. Concept and Definitions of a Business Model}

The concept of a business model could date back to the 1990s and the research evolution experienced four main stages. The first stage is the emerging stage of business model. In around 2000 with the rapid development of information technology and the internet boom, several e-business models emerged and some of them turned to be very successful [19].At this stage, the research on business model emerged, with an emphasis on the definitions and classifications. In the second stage, the components and building blocks were proposed by several studies to describe a business model in a systematic way [20]. However, different researchers from different background proposed varied building blocks, and they could not reach unanimous agreements among each other. The next stage, researchers focused on the case study of business model implementation [21], [22]. The importance of business model innovation is commonly agreed with practitioners and academics [23]. In the fourth stage, the concept of sustainability draws increasing attention, as researchers agree on the fact that a company should undertake corporate social responsibility and pay attention to sustainable development. Some researchers fill the gap between business model design and implementation from the sustainability perspective [24]. Fig. 4 illustrates the four stages of the business model evolution.

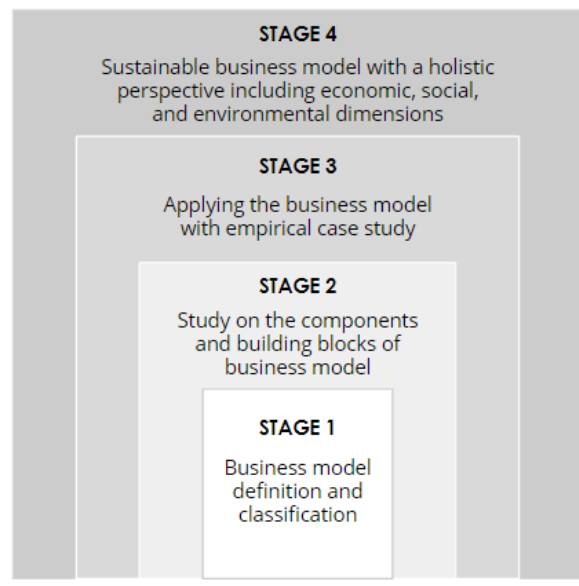

Fig. 4. Evolution of business model research.

Among the four stages in the Fig. 4, the first stage is of great importance because understanding the definitions of business models is an essential process for developing innovative business models. During the stage of business model definitions, there are several studies with varied definitions about business models. For example, Stewart and Zhao define business model as "a statement of how a firm will make money and sustain its profit stream over time" [25]. Chesbrough and Rosenbloom state that business models are descriptions of how a firm or an organization does business [26]. Furthermore, Chesbrough and Rosenbloom propose that a business model is a "focusing device that mediates between technology development and economic value creation" [27].

Morris et al. state that the business model is a concise representation of how an interrelated set of decision variables in the areas of venture strategy, architecture, and economics are addressed to create sustainable competitive advantage in 
defined markets [28]. Richardson proposes that the business model could be seen as the conceptual and architectural implementation of a business strategy and as the foundation for the implementation of business processes [29].

Osterwalder and Pigneur define business model as the rationale of how an organization creates, delivers and captures value. Teece defines the business model as the architecture of a firm's value creation, delivery and appropriation mechanisms provides the basis for a much needed dimensionalization of the business model constructs [30]. Casadesus-Masanell and Ricart suggest that business model is "a reflection of the firm's realized strategy" [31]. Gassmann et al. summarize business model as the understanding in four dimensions: Who, What, How and the Value [32].

Joyce and Paquin develop three layers of a business model, which include the economic factors, social benefits, and environmental impact from the sustainable perspectives [8]. The case of Nestle Nespresso was then reanalyzed from a holistic view of economic, environmental and social perspectives.

As it can be seen from the variety of definitions, "value" is the most important characteristic of a business model. In addition, "strategy" and "sustainability" appear frequently, which means that a business model should reflect an organization's strategy and sustainability. Based on the above definitions, it is reasonable to draw the conclusion that business models should address "value".

\section{B. Building Blocks of a Business Model}

Amit and Zott propose three key building blocks for a business model from the transaction perspective. They include transaction contents, transaction structure, and transaction governance [33]. Transaction contents include the goods, information, and capabilities that are required to exchange. They argue that transaction cost could be reduced via a properly designed business model.

Additionally, Krumeich et al. divide a business model into five aspects, including value offering, value capture, value creation, cooperation, and financial model [20]. Chesbrough and Rosenbloom suggest that business model should consists of six building blocks, value proposition, target market, value chain for creating and distributing the offerings, competitive strategy, cost and revenue model, and a value network [26]. Moreover, Bocken et al. propose four building blocks for a business model, including value proposition, value creation, value capture, and value delivery [13]. Furthermore, they also pointed out from the sustainable development perspective, that is, value proposition should include not only the economic value but the ecological benefits and social value as well. Richardson develops a business model that consists of three main building blocks: value proposition, value creation and delivery, and value capture [29]. The value proposition includes the concepts of what does a company offer and who will benefit from the value offering. However, we argue that it is better to separate the value beneficiary components and value propositions, which could help clearly identify who will benefit from the business offerings.

In addition to value proposition, Gassmann et al. propose the Who-what-how-why business model that describes a business model of which the first two (who and what) address its external dimensions and the second two (how and why) address its internal dimensions [32]. They also propose 55 business model and case studies to illustrate how the business model works in the real world.

TABLE I: SELECTED BUILDING BLOCKS OF A BusinesS MODEL

\begin{tabular}{|c|c|c|c|}
\hline Authors & Year & $\begin{array}{l}\text { No. of } \\
\text { building } \\
\text { blocks }\end{array}$ & Specific components \\
\hline Timmers [19] & 1998 & 5 & $\begin{array}{l}\text { Product or service flows, } \\
\text { business actors and their roles, } \\
\text { potential benefits of the } \\
\text { actors, sources of revenue, } \\
\text { and marketing strategy. }\end{array}$ \\
\hline $\begin{array}{c}\text { Amit and Zott } \\
{[33]}\end{array}$ & 2001 & 3 & $\begin{array}{l}\text { Transaction contents, } \\
\text { transaction structure, and } \\
\text { transaction governance }\end{array}$ \\
\hline Hamel [34] & 2001 & 4 & $\begin{array}{l}\text { Core strategy, strategy } \\
\text { resources, value network, } \\
\text { customer interface. }\end{array}$ \\
\hline $\begin{array}{c}\text { Chesbrough\& } \\
\text { Rosebloom [26] }\end{array}$ & 2002 & 6 & $\begin{array}{l}\text { Value proposition, target } \\
\text { market, internal value chain, } \\
\text { value network, competitive } \\
\text { strategy, cost structure and } \\
\text { revenue model. }\end{array}$ \\
\hline Morris [28] & 2005 & 3 & $\begin{array}{l}\text { Factors related to the offering, } \\
\text { market factors, internal } \\
\text { capability factors, competitive } \\
\text { strategy, economic factors, } \\
\text { and investor factors. }\end{array}$ \\
\hline Massa [35] & 2011 & 3 & $\begin{array}{c}\text { Value Proposition, value } \\
\text { creation and delivery, and } \\
\text { value capture }\end{array}$ \\
\hline Chatterjee [36] & 2013 & 3 & $\begin{array}{c}\text { Value Proposition, value } \\
\text { creation and delivery, and } \\
\text { value capture. }\end{array}$ \\
\hline $\begin{array}{c}\text { Bocken et al. } \\
{[13]}\end{array}$ & 2016 & 4 & $\begin{array}{l}\text { Value Proposition, value } \\
\text { creation and delivery, value } \\
\text { capture. }\end{array}$ \\
\hline Barth et al. [4] & 2017 & 4 & $\begin{array}{l}\text { Value Proposition, value } \\
\text { creation and delivery, value } \\
\text { capture, and value intention. }\end{array}$ \\
\hline
\end{tabular}

Table I summarizes the selected building blocks from literature. As can be seen from the Table I, value and its elements have been the most frequently identified as key building blocks in the literature. In addition, "transaction" and "strategy" are also seen as important components for a business model.

\section{Sustainable Business Models}

However, traditional commercial business models usually focus on only obtaining economic revenue and are in ignorance of corporate sustainability. As sustainable development draws increasing concern in recent years, scholars realized that business model should not only focus on the economic perspective, but also should consider social 
and environmental perspectives. Some companies would like to innovate their business model from selling products to the sale of service in order to move to a circular business model [37]. Many business model innovations are involved with sustainability [38], [39]. For instance, Geissdoerfer et al. design the process for business model innovation, which include concept design, detail design, and implementation [24].

Geissdoerfer et al. discuss the methods to bridge the design and implementation gap during the business model process [40]. Laasch examines the differences between traditional commercial business model and sustainable business model. The value logics of sustainable business models should integrate social, environmental and economic value. Sustainable business models focus on benefitting a diverse set of stakeholders. The differences mainly are in that a traditional business model merely focuses on economic value capture, making profit for the companies, whereas a sustainable business model has a widely range of stakeholders, i.e. more value beneficiaries.

\section{RECOMMENDATIONS FOR Future BuSINESS MODEL DEVELOPMENT}

Based on the thematic analysis in the previous section, it is evident that value and its elements are highlighted in the business model definitions, building blocks and sustainability in the literature. A business model should help identify value, create value, deliver value and capture value. In this regard, we make the following recommendations for future business model development.

A business model should address four key dimensions in order to create a complete value circle. (1) Value beneficiary - who will benefit from the value offering? (2) Value proposition - what is the company's offering? (3) Value chain - how do we achieve the value proposition? (4)Value capture- why does a business model work commercially? The complete value circle with the four dimensions is shown in Fig. 5. This section also provides the justification of the four building blocks.

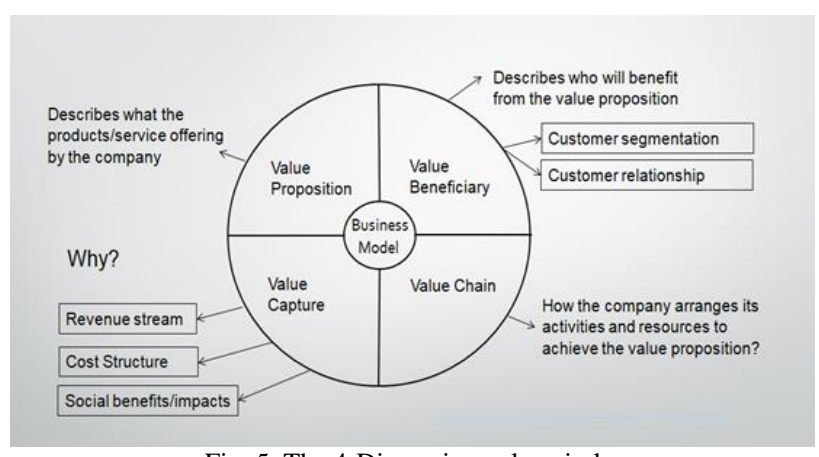

Fig. 5. The 4-Dimension value circle.

\section{A. Value Beneficiary}

One of the important building blocks is value beneficiaries, which usually refer to stakeholders. It describes who will benefit from the value proposition and which market segments to target at [32]. Based on different markets a business targets at, a business can be classified as local business, regional business or international business. As a business gradually grows from a small start-up to a larger company, it means that the expansion of the business from local to international with greater influence and more beneficiaries. Furthermore, this building block includes dealing with customer relationships. Good relationship with customers could help improve customer loyalty. Customer relationship involves effective interactions with the target customers. A sustainable business needs to achieve continuous improvement of current communication channels and explore new relationships with potential customers.

From a holistic point of view, successful business models should help companies to create value to beneficiaries, ranging from customers, suppliers, and communities.

\section{B. Value Proposition}

The second key building block is value proposition. Most papers have agreed on this component, which is regarded as the core component of a business model [41], [42]. Value proposition describes what product and/or service offering of the company. Some successful companies offer both products and service, to increase the competitiveness. For manufacturing industry, most value proposition predominantly focuses on certain products, innovated with technology [43]. While for healthcare industry, most value proposition predominantly focuses on service. Some researchers studied the business model innovation in hospital management and developed patients-oriented business models from the patients-caring point of view.

\section{Value Chain}

The third dimension is value chain. Value chain describes how a business arranges its activities and resources to achieve the value proposition. It involves the main activities that are necessary for a business to provide its offerings. Some studies also called this process value exchange [9], [44].

The value chain building block includes several subconstructs, as shown in Fig. 6. They are key resources, key activities, key partnerships, and distribution channels [32]. Key resources are defined as the assets that are required to achieve the value proposition. The resources include intellectual, physical, financial, and human resources, as well as technology. Key activities refer to what a firm must do to create the value proposition. Key partners include suppliers, joint ventures, and strategy alliance. For some start-up business, joint ventures could help reduce some risks.

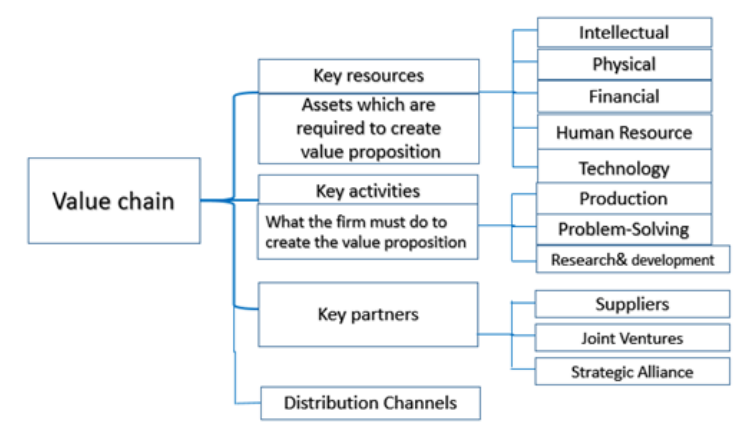

Fig. 6 Subconstructs of value chain. 


\section{Value Capture}

The fourth dimension is value capture. The value capture has close relationship with the value proposition as it describes how the profit is realized i.e. why the business will survive and thrive. From economic perspective, value capture includes revenue model and cost structure [45]. From social perspective, it should include social benefits and impacts. For example, in the healthcare industry, a successful robust and resilient business model should not only bring itself value captures, but also relieve the pains of patients and increase their social welfare.

\section{CONCLUSION}

Business model research has been ongoing for more than a decade. Different scholars hold different views about the concept of business model and from multidisciplinary background. The interests in business model development is growing rapidly especially since 2016 . The development of a sustainable and innovative business model is of great importance in the current fierce competitions. Understanding the concept and key components of a business model is the foundation to business model innovation. Based on a systematic literature review, this article recommends four key dimensions for future business model development, namely value proposition, value beneficiary, value chain, and value capture. These four dimensions summarize the main components of a business model that are interdependent with each other. When all four dimensions are addressed, a complete value circle can be created aiming for a healthy, sustainable business. Value proposition is regarded as the key building block of a business model, as it describes what benefits a business creates. Value beneficiary refers to who will benefit from the value proposition. Value chain is closely related to the value proposition because it describes how the value can be achieved. Value capture describes why a business will survive and thrive. This article helps make progress towards better understanding of the concept of business model and contributes to future development of innovative, sustainable business models.

\section{CONFLICT OF INTEREST}

The authors declare no conflict of interest.

\section{AUTHOR CONTRIBUTIONS}

Bin Gao conducted the research and wrote the original draft of the paper; Bin Gao and Shaofeng Liu proposed the research methodology; Shaofeng Liu and Genhua Pan contributed to the review and supervision; Aira Patrice R. Ong contributed to the editing; all authors had approved the final version.

\section{ACKNOWLEDGMENT}

This work is supported by two European Horizon 2020 Projects under the scheme of Marie Skłodowska-Curie Innovative Training Networks: BBDiag and AiPBAND. We appreciate the funding from the European Commission.

\section{REFERENCES}

[1] J. Magretta, "Why business models matter," Harv. Bus. Rev., vol. 80, no. 5, pp. 86-133, May 2002

[2] A Beltramello, "Why new business models matter for green growth," OECD Green Growth Papers, 2013.

[3] B. Bourque, "Business model innovation, perhaps the most important type of innovation," ACSM's Health \& Fitness Journal, vol. 13, no. 1, pp. 39-40, 2009

[4] H. Barth, P.-O. Ulvenblad, and P. Ulvenblad, "Towards a conceptual framework of sustainable business model innovation in the agri-food sector: A systematic literature review," Sustainability, vol. 9, no. 9, p. 1620, 2017.

[5] N. J. Foss and T. Saebi, "Fifteen years of research on business model innovation," Journal of Management, vol. 43, no. 1, pp. 200-227, 2017.

[6] B. W. Wirtz, A. Pistoia, S. Ullrich, and V. Göttel, "Business models: Origin, development and future research perspectives," Long Range Planning, vol. 49, no. 1, pp. 36-54, 2016.

[7] A. Osterwalder and Y. Pigneur, Business Model Generation: A Handbook for Visionaries, Game Changers, and Challengers, John Wiley \& Sons, 2013.

[8] A. Joyce and R. L. Paquin, "The triple layered business model canvas: A tool to design more sustainable business models," Journal of Cleaner Production, vol. 135, pp. 1474-1486, 2016.

[9] M. Hossain, "Business model innovation: Past Research, current debates, and future directions," Journal of Strategy and Management, vol. 10, issue 3, pp.342-359, 2017.

[10] P. H. Fabel, T. Wagner, B. Ziegler, P. A. Fleming, and R. E. Davis, “A sustainable business model for comprehensive medication management in a patient-centered medical home," J. Am. Pharm. Assoc., vol. 59, no. 2, pp. 285-290, Mar. 2019.

[11] V. Miladinović et al., "European business excellence model on sustainable development," Knowledge Based Sustainable Economic Development, 2018.

[12] C. S. Mishra, Is the Business Model Efficient and Sustainable? Reconfigure the Business Model, Springer, 2015.

[13] N. M. P. Bocken, I. Weissbrod, and M. Tennant, "Business model experimentation for sustainability," Sustainable Design and Manufacturing, pp. 297-306, 2016

[14] M. Yang, D. Vladimirova, and S. Evans, "Creating and capturing value through sustainability," Research-Technology Management, vol. 60, no. 3, pp. 30-39, 2017

[15] P. Lehoux, G. Daudelin, B. Williams-Jones, J.-L. Denis, and C. Longo, "How do business model and health technology design influence each other? Insights from a longitudinal case study of three academic spin-offs," Research Policy, vol. 43, no. 6, pp. 1025-1038, 2014.

[16] J. D. Van-Vactor, "Collaborative leadership model in the management of health care," Journal of Business Research, vol. 65, no. 4, pp. 555-561, 2012.

[17] M. A. Pfannstiel and C. Rasche, Service Business Model Innovation in Healthcare and Hospital Management: Models, Strategies, Tools, Springer, 2016.

[18] C. M. Lopes, A. J. Scavarda, M. N. M. de Carvalho, and A. L. Korzenowski, "The business model and innovation analyses: The sustainable transition obstacles and drivers for the hospital supply chains," Resources, vol. 8, no. 1, p. 3, 2018.

[19] P. Timmers, "Business models for electronic markets," Electronic Markets, vol. 8, no. 2, pp. 3-8, 1998.

[20] J. Krumeich, D. Werth, and P. Loos, "Business model dynamics Towards a dynamic framework of business model components," Lecture Notes in Business Information Processing, pp. 190-215, 2015

[21] M. Sosna, R. N. Trevinyo-Rodríguez, and S. Ramakrishna-Velamuri, "Business model innovation through trial-and-error learning," Long Range Planning, vol. 43, no. 2-3, pp. 383-407, 2010.

[22] C. Battistella and E. Pessot, Investigating Companies' Journey Toward Business Model Innovation Through Case Study Research, 2019.

[23] N. J. Foss and T. Saebi, "Business models and business model innovation," Business Model Innovation, pp. 1-23, 2015.

[24] M. Geissdoerfer, P. Savaget, and S. Evans, "The cambridge business model innovation process," Procedia Manufacturing, vol. 8, pp. 262-269, 2017.

[25] D. W. Stewart and Q. Zhao, "Internet marketing, business models, and public policy," Journal of Public Policy \& Marketing, vol. 19, no. 2, pp. 287-296, 2000.

[26] H. Chesbrough, "The role of the business model in capturing value from innovation: Evidence from Xerox Corporation's technology spin-off companies," Industrial and Corporate Change, vol. 11, no. 3, pp. 529-555, 2002. 
[27] H. Chesbrough, "Business model innovation: It's not just about technology anymore," Strategy \& Leadership, vol. 35, no. 6, pp. 12-17, 2007.

[28] D. Morris, "A new tool for strategy analysis: the opportunity model," Journal of Business Strategy, vol. 26, no. 3, pp. 50-56, 2005.

[29] J. E. Richardson, "The business model: An integrative framework for strategy execution," Strateg. Chang., 2008.

[30] D. J. Teece, "Business models, business strategy and innovation," Long Range Planning, vol. 43, no. 2-3, pp. 172-194, 2010.

[31] R. Casadesus-Masanell and J. E. Ricart, "From strategy to business models and onto tactics," Long Range Planning, vol. 43, no. 2-3, pp. 195-215, 2010.

[32] O. Gassmann, K. Frankenberger, and M. Csik, The Business Model Navigator: 55 Models That Will Revolutionise Your Business, Ft Press, 2014.

[33] R. Amit and C. Zott, "Value creation in e-business," Strategic Management Journal, vol. 22, no. 6-7, pp. 493-520, 2001.

[34] G. Hamel, "Leading the revolution," Journal of Product Innovation Management, vol. 18, no. 3. pp. 212-213, 2001

[35] S. Massa and S. Testa, "Beyond the conventional-specialty dichotomy in food retailing business models: An Italian case study," Journal of Retailing and Consumer Services, vol. 18, no. 5, pp. 476-482, 2011.

[36] S. Chatterjee, "Simple rules for designing business models," California Management Review, vol. 55, no. 2, pp. 97-124, 2013

[37] A. Tukker, "Product services for a resource-efficient and circular economy - A review," Journal of Cleaner Production, vol. 97, pp. 76-91, 2015

[38] T. A. Hemphill, "The global food industry and 'creative capitalism': The partners in food solutions sustainable business model," Busines and Society Review, vol. 118, no. 4, pp. 489-511, 2013.

[39] S. Jørgensen and L. J. T. Pedersen, "Why sustainable business model innovation?" Restart Sustainable Business Model Innovation, pp. 3-11, 2018.

[40] M. Geissdoerfer, D. Vladimirova, and S. Evans, "Sustainable business model innovation: A review," Journal of Cleaner Production, vol. 198 pp. 401-416, 2018

[41] B. Carlson, "In Search of the perfect business model: As personalized medicine moves into the mainstream, makers of diagnostics must face a new economic reality. How to develop a value proposition in a healthcare market that is becoming increasingly elastic?" Biotechnol. Healthc., vol. 9, no. 1, pp. 20-23, Spring 2012.

[42] H. Peng, "Analysis of e-business model classification framework based on value proposition," in Proc. 2010 International Conference on E-Business and E-Government, 2010.

[43] S. W. Short, N. M. P. Bocken, C. Y. Barlow, and M. R. Chertow, "From refining sugar to growing tomatoes," Journal of Industrial Ecology, vol 18 , no. 5, pp. 603-618, 2014.

[44] O. Laasch, "Beyond the purely commercial business model: Organizational value logics and the heterogeneity of sustainability business models," Long Range Planning, vol. 51, no. 1, pp. 158-183, 2018.

[45] A. Osterwalder, Y. Pigneur, and C. L. Tucci, "Clarifying business models: Origins, present, and future of the concept," Communications of the Association for Information Systems, vol. 16, 2005.

Copyright $\odot 2020$ by the authors. This is an open access article distributed under the Creative Commons Attribution License which permits unrestricted use, distribution, and reproduction in any medium, provided the original work is properly cited( $\underline{\text { CC BY 4.0) }}$

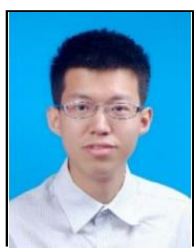

Bin Gao was born in Hebei, China. He obtained his bachelor of management degree in construction project management at Tianjin University, Tianjin, China in 2012 and master of science degree at Purdue University, Indiana, U.S.A. in 2013.

He is currently a Marie Curie early stage researche (ESR) in the Faculty of Business, University of Plymouth as part of the BBDiag (Blood Biomarker for Diagnosis of early stage of Alzheimer's disease) Project. Prior to this, he worked as a research analyst at Futures First (Shanghai) Investment Consulting Co. Ltd., China. His current research interests include business with management and business model innovation
Mr. Bin Gao has been awarded as the designation of Chartered Financial Analysts by the CFA Institute, Virginia, U.S.A. He has publications in journal and conference proceedings. The title of the publication is Dynamic Measurement and Evaluation on Foreign Exchange Risks of International Construction Projects.

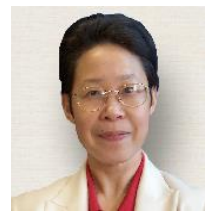

Shaofeng Liu obtained her $\mathrm{PhD}$ degree from Loughborough University, UK.

She is a professor of operations management and decision making at University of Plymouth, UK. She is the research director for the Product and Service Value Chain Group, specializing in digital business, knowledge management, decision-making, and value chain innovation. She sits on the Management Board for Euro Working Group on Decision Support Systems. She is currently a senior editor for Cogent Business and Management, and on Editorial Boards for a number of international journals.

Prof. Liu has undertaken a number of influential research projects funded by UK research councils and the European Commission with a total value over $€ 40 \mathrm{M}$. She is currently principal investigator and co-investigator for 4 EU projects ( 3 of which are funded by Horizon 2020 and one by Erasmus Plus) and 1 project funded by UK research council - Innovate UK. She has published over 150 peer-reviewed research papers.

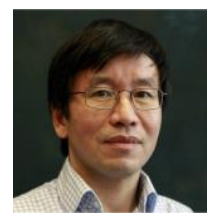

Genhua Pan graduated from Zhejiang University of China in 1981, worked in the Chinese Academy of Science until 1988 when he took a year visiting scholarship to Loughborough University of Technology. He then joined Plymouth University for $\mathrm{PhD}$ studies, gained the $\mathrm{PhD}$ in thin film data storage technology in 1993. He took a post-doc fellowship before becoming a lecturer in 1996, appointed reader in 2004 and professor in 2006 .

$\mathrm{He}$ is a professor and the head of Wolfson Nanomaterials \& Devices Laboratory of Plymouth University. He has over 30 years of research and teaching experience in micro/nano scale thin films and devices and electronic engineering. His current research interest encompasses graphene \& 2D materials/devices, biosensing and molecular diagnostic technology, renewable energy/solar cells, spintronics and magnetic data storage.

Prof. Pan worked in a number of research institutions worldwide as a visiting researcher, e.g., Sony Research Centre (Yokohama, Japan), Akita Institute of Technology (Akita, Japan), and Seagate Technology (Northern Island). He was successfully led or participated in many national and international research projects with total funding value of over $£ 12 \mathrm{M}$. He is the founder of the Wolfson Lab at Plymouth. He served as UK Magnetic Society Committee member and also independent expert reviewer for European Commission project reviews. He has published over 100 journal and conference papers, 3 book chapters and 6 patents. He is the coordinator of the BBDiag Project.

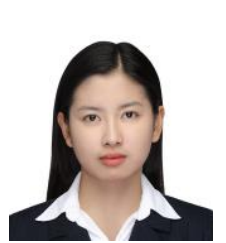

Aira Patrice R. Ong was born in Manila, Philippines. She obtained her bachelor of science and masters of science (Honours Program) degree in manufacturing engineering at De La Salle University (DLSU), Philippines with Latin Honours (Cum Laude) and as a engineering research in Department of Science and Technology and Development for Technologies (DOST-ERDT) Scholar in 2017.

She is currently a Marie Curie early stage researcher (ESR) in the University of Plymouth as part of the Project AiPBAND (An Integrated Platform for Developing Brain CANcer Diagnostic Techniques). From 2015 to 2018, she has been a researcher in the Biomedical Devices Innovation and e-Health Research Group. She served as the lead researcher of the "AGAPAY Project: A Robotic Exoskeleton for Upper Extremity Rehabilitation."

Miss Ong was awarded Gold Thesis for Most Outstanding Graduate Thesis for her MSc research project entitled, "Design of a Hand Wearable Device for Grasping with Kinematic Simulation." She has published in journals and conference proceedings on biomedical engineering, robotics and management. 